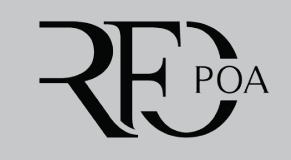

\title{
TRICHO-DENTO-OSSEOUS SYNDROME: A BRIEF REVIEW FOR DENTISTRY
}

\author{
Síndrome trico-dento-óssea: uma breve revisão \\ para odontologia
}

\author{
Dicardo Barbosa Limaa , (D) Taigor Alves Azevedoa, (D) Amanda Lopesa, \\ Aquiles Sales Craveiro Sarmento ${ }^{b}$, (DD Carlos Eduardo Palanch Repeke
}

\begin{abstract}
Introduction: Tricho-dento-osseous syndrome is a ultra-rare ectodermal dysplasia related to genetic alterations in the $D L X 3$ gene of interest to the health sciences due to its clinical manifestations. Aim: To synthesize the scientific evidence about tricho-dento-osseous syndrome, especially for dentistry. Methods: A bibliographic search was performed in the MEDLINE / PubMed, Web of Science and Scopus databases. A search strategy with descriptors was applied to all databases mentioned to reach scientific articles. The articles reached in all databases had their titles and abstracts read in search of adaptation to the proposed objective. There was no restriction on the year of publication, country or language. Literature review: Patients diagnosed with this syndrome have dental enamel defects and severe taurodontism, especially in the permanently lower first molars. In addition to these signs, other manifestations may be associated, such as curly hair, increased bone density and changes in craniofacial bones. The diagnosis of tricho-dento-osseous syndrome can be challenging due to the heterogeneity and wide phenotypic variation presented by patients with $D L X 3$ mutations, since this gene is associated with several functions, especially related to cell differentiation and biomineralization. In addition, it is necessary to consider that other dental anomalies may be confused with tricho-dento-osseous syndrome, especially cases of imperfect amelogenesis associated with taurodontism. Conclusion: For dentistry, oral manifestations caused by this syndrome become relevant for diagnostic and therapeutic purposes, although there are no clinical protocols for dental management of this patients.
\end{abstract}

Keywords: Tricho-dento-osseous syndrome. Ectodermal dysplasia. Oral manifestations. Review literature as topic.

\section{RESUMO}

Introdução: A síndrome trico-dento-óssea é uma displasia ectodérmica ultra-rara relacionada a alterações genéticas no gene $D L X 3$ de interesse para as ciências da saúde devido à suas manifestações clínicas. Objetivo: Sintetizar as evidências científicas sobre a síndrome trico-dento-óssea, especialmente para odontologia. Materiais e métodos: Uma pesquisa bibliográfica foi realizada nas bases de dados MEDLINE/PubMed, Web of Science e Scopus. Uma estratégia de busca com descritores foi aplicada em todas as bases de dados mencionadas para alcançar os artigos científicos. Os artigos alcançados em todas as bases de dados tiveram seus títulos e resumos lidos em busca da adequação ao objetivo proposto. Não houve restrição quanto ao ano de publicação, país ou idioma. Revisão de literatura: Os pacientes diagnosticados com essa síndrome apresentam defeitos no esmalte dentário e taurodontismo severo, principalmente nos primeiros molares permanentemente inferiores. Além desses sinais, outras manifestações podem estar associadas, como cabelos crespos, aumento da densidade óssea e alterações nos ossos craniofaciais. O diagnóstico da síndrome tricodento-óssea pode ser desafiador devido à heterogeneidade e ampla variação fenotípica apresentada pelos pacientes com mutações em $D L X 3$, uma vez que esse gene está associado a várias funções, principalmente relacionadas à diferenciação e biomineralização celular. Além disso, é necessário considerar que outras anomalias dentárias podem ser confundidas com a síndrome trico-dento-óssea, principalmente nos casos de amelogênese imperfeita associada ao taurodontismo. Conclusão: Para a odontologia, as manifestações orais causadas por essa síndrome tornam-se relevantes para fins diagnósticos e terapêuticos, embora não existam protocolos clínicos para o tratamento odontológico específico destes pacientes.

Palavras-chave: Doenças genéticas inatas. Displasia ectodérmica. Manifestações bucais. Literatura de revisão como assunto.

\footnotetext{
${ }^{a}$ Departamento de Odontologia de Lagarto, Universidade Federal de Sergipe, Campus Prof. Antônio Garcia Filho, Lagarto, SE, Brasil.

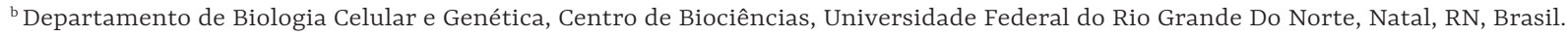
Autor de correspondência: Ricardo Barbosa Lima - E-mail: ricardoblima@academico.ufs.br Data de envio: 05/03/2020 | Data de aceite: $12 / 03 / 2020$
} 


\section{INTRODUCTION}

The tricho-dento-osseous syndrome (TDOS) is an ultra-rare syndromic condition with an autosomal dominant inheritance. It is an uncommon ectodermal dysplasia resulting from interactions between epithelium and mesenchyme. Ectodermal dysplasias are hereditary changes in tissues that develop from the embryonic ectoderm, leading to inadequate tissue differentiation. With wide phenotypic variation, TDOS causes changes in the hair, teeth and bones of affected individuals ${ }^{1-3}$.

The heterogeneity of phenotypes makes it difficult to accurately diagnose of TDOS, although changes in dental elements may be consistent in differentiating it from other syndromes with oral manifestations ${ }^{4,5}$. The diagnosis often occurs in the first year of life, when the first signs of the syndrome can be observed. Also, wide phenotypic variation may be due to environmental combined to genetic factors. The onset of TDOS are mutations different regions of the distal-less homeobox 3 ( $D L X 3)$ gene $^{2-4}$.

Thus, considering the importance of TDOS for dentists and the need to understand oral manifestations, this review aims to synthesize the scientific evidence about tricho-dento-osseous syndrome, especially for dentistry.

\section{MeTHODS}

A bibliographic search was carried out in the MEDLINE/PubMed, Web of Science and Scopus databases. A search strategy with descriptors was applied in all the aforementioned databases to reach the scientific articles: "dentistry" [MeSH terms] AND "tricho-dento-osseous syndrome" [MeSH terms]). The articles reached in all databases had their titles and abstracts read in search of adequacy to the proposed objective. There were no restrictions on the year of publication, country or language.

As it is an ultra-rare syndrome, little evidence is available in the databases. We selected studies available fully that addressed relevant aspects about the trico-dento-osseous syndrome for dental sciences, involving a historical, molecular and clinical perspective.

\section{LITERATURE REVIEW}

Retrospectivity, the first scientific evidence of TDOS was reported by Robinson et al., ${ }^{6}$ Lichtenstein and Warson ${ }^{7}$ and Lichtenstein et al. ${ }^{8}$ The authors initiated case studies that investigated phenotypic characteristics in individuals and families with enamel hypoplasia, seeking to understand what other changes were associated with this dental defect.

Moving forward in the timeline, with the consolidation of TDOS as a syndrome, Quattromani et al. ${ }^{9}$ and Shapiro et al. ${ }^{10}$ initiated the first studies to identify clinical variations. In their results, based on clinical evidence, the authors suggested the first classification for TDOS into three subtypes according to the phenotypic variation presented. Also, the same authors started discussions about genetic mutations and heterogeneity observed in TDOS.

Seow ${ }^{11}$ published a literature review that included and evaluated case reports of TDOS and imperfect amelogenesis. This was one of the pioneering studies in understanding the phenotypic variations of TDOS and an initial toe in discussions about the differential diagnosis between this syndrome and other dental anomalies. In the same year, Seow ${ }^{12}$ investigated the relationship between the severity of taurodontism, TDOS, and imperfect amelogenesis. The author was a pioneer in identifying that severe taurodontism is associated only with TDOS and is unrelated to imperfect amelogenesis. 
DLX3 gene mutations are the molecular explanation to TDOS. Molecular and genetic approaches to TDOS had their milestones with the identification of mutations in $D L X 3$ gene, located on chromosome 17q21, in families with TDOS ${ }^{13-15}$. In addition to these, Wright et al. ${ }^{16}$ researched phenotypic and genotypic variations in TDOS. In their findings, the authors identified that hair alterations, enamel defects and taurodontism have wide clinical variation, even with high penetrance in patients diagnosed with TDOS.

The DLX3 protein is related to craniofacial growth and development, acting on the standardization of embryonic ectoderm, hair follicles, and dental amelogenesis. DLX3 is a transcription factor important to bone, tooth and hair embryogenesis. Mutations localized in different regions of $D L X 3$ are associated with the clinical manifestations range of the syndrome, justifying the occurrence of mild to severe cases ${ }^{2,3,17}$.

The alterations that affect the C-terminus region of DLX3 might be associated with the severity of some manifestations in patients diagnosed with TDOS, indicating that certain $D L X 3$ mutations are associated with low or high severity phenotypes of this syndrome. Variations in that region are important to the failure of the binding of DLX3 protein with DNA to exercise its activity as a transcription factor ${ }^{18,19}$.

DLX3 protein is associated with tissue biomineralization throughout the human skeleton, regulating the deposition of minerals in tissues. In knockdown models for $D L X 3$, it is observed that there is a negative modulation of the expression of enamel mineral matrix genes, crucial to amelogenesis ${ }^{20,21}$.

Besides, some $D L X 3$ mutations identified can cause late cell senescence, modifying bone aging and decreasing bone loss. Studies in experimental models indicate that the osteogenic potential of mesenchymal stem cells may increase when $D L X 3$ genetic mutations are present. These findings can be interpreted as a possible cause for bone density changes observed in some patients with TDOS ${ }^{3}$.

Recently, c.533 A > G as a DLX3 mutation that may cause decreased differentiation of dental pulp odontogenic cells was reported, indicating an influence of this gene on dentin formation and mineralization. One year later, that same group found that microRNA-675 positively acts in the process of odontogenic cell differentiation. It modulates $D L X 3$ gene expression by inhibition of its promoter methylation ${ }^{22,23}$.

Dental and craniofacial manifestations are frequently in this syndrome. TDOS manifests clinically widely in affected individuals, however, some characteristics are frequently observed. Curly or wavy hair has been identified in a series of studies with patients diagnosed with TDOS and some authors consider it one of the characteristics that drive the investigation and diagnosis of this syndrome in children. However, scientific evidence reports that capillary changes are not present in all individuals with TDOS, have wide phenotypic variation among individuals within the same family and may change after childhood, as some lose this characteristic over time $e^{3,5,24}$.

On the other hand, taurodontism and enamel hypoplasia are characteristics strongly associated with diagnoses with TDOS. Nevertheless, taurodontism (pulp chamber enlargement) still causes divergences in the clinical diagnosis between amelogenesis imperfecta and TDOS. This diagnostic confusion, exemplified by the clinical case reported by Hegde and Srikanth ${ }^{25}$, should take seriously the fact that it is possible to observe a mild degree of taurodontism in patients with imperfect amelogenesis, although severe cases of taurodontism are associated with TDOS. However, it is still not possible to understand whether it is an imperfect threat, an incomplete expression of TDOS or a spectrum of disease $e^{4,5,26,27}$.

Changes in dental enamel may be considered the most significant in patients diagnosed with TDOS. They include teeth with a color change in shades between yellow and brown. In addition, a drastic reduction in enamel thickness can be found, ranging from $12.5 \%$ to $60 \%$ of 
the thickness of a healthy tooth. Histologically, it is common to observe zones of aprismatic enamel, hypocalcified and with less amount of mineral matrix, together with changes in dentinal tubules and Tomes granular layer ${ }^{4,28,29}$.

Currently, it is understood for diagnostic purposes that generalized enamel hypoplasia and severe taurodontism characterize TDOS and allow differential diagnosis of imperfect amelogenesis, since severe taurodontism is not common in the latter and both conditions are present in all individuals with TDOS. When assessing taurodontism, its occurrence in the permanent lower first molar is a change strongly associated with a true dental anomaly and its severity can be measured radiographically by the relationship between the dimensions of the root and the crown of the tooth ${ }^{4,24,30}$.

Craniofacial manifestations remain poorly understood in patients with TDOS. Dolichocephalic profile, maxillary retrognathism, and mandibular prognathism were identified in patients with TDOS; however, studies measuring such cephalometric characteristics suggest that such alterations may be the result of environmental and genetic factors unrelated to TDOS. Besides, it is necessary to consider that the inclusion of patients with different phenotypic severities of TDOS may make statistical analyzes difficult to determine significant craniofacial changes ${ }^{24,31}$.

Kula et al. ${ }^{31}$ found that the length of the mandibular body, the size and the angle of the skull base were greater in patients with TDOS, as well as the thickness of some craniofacial bones and lower visibility of the frontal sinuses. On the other hand, Nguyen et al. ${ }^{24}$ found no differences in skull base size and angle. However, similarly to Kula et al. ${ }^{31}$ identified larger measurements on mandibular body length, as well as higher measurements of lower facial third height compared to standard values. Nguyen et al..$^{24}$ also did not verify mandibular prognathism in patients with TDOS comparing to their controls. However, he indicated the possibility of a skeletal class III appearance when there is a retracted jaw.

Associated with severe taurodontism (in primary or permanent dentitions) and enamel hypoplasia, individual and family case reports indicate that patients diagnosed with TDOS may have brittle nails, increased skull bone density (bone sclerosis), severe dental attrition and abscesses ${ }^{4,32}$.

The other clinical manifestations that can be identified in patients diagnosed with TDOS are variable and not completely understood. Unusually, Mayer et al. ${ }^{33}$ reported a case of severe atopic dermatitis in a patient diagnosed with TDOS. Similarly, Al Kaissi et al. ${ }^{34}$ reported a case of melorheostosis mimicking TDOS in a patient with similar phenotypic characteristics. In addition to these findings, two studies indicate an association between chromosome 17q21 deletion and the occurrence of TDOS associated with cognitive disorders and osteogenesis imperfecta, making room for new correlations between $D L X 3$ genetic alterations and other conditions ${ }^{35,36}$.

It is essential for the diagnosis and management of patients with TDOS to observe other characteristics besides enamel hypoplasia and taurodontism, such as changes in hair, bones, and nails. We should investigate the occurrence of skin diseases such as atopic dermatitis and other systemic manifestations. Early diagnosis may favor the management of dental changes ${ }^{2,37}$.

Teeth affected by enamel defects often present color changes, hypersensitivity, caries disease and progressive loss of dental structure. It is common to observe the need for restorative, endodontic and prosthetic treatments and retreatments in patients with dental enamel defects. The difficulty of adherence and the characteristics of the dental remnant impair adhesive dental procedures and reduce the survival of treatments over time $e^{37,38}$.

There are no protocols for patients with generalized dental enamel defects and multidisciplinary dental treatment is essential for a good prognosis and oral health of individuals. However, the first step may be complete dental documentation, including full-mouth radiographic examinations ${ }^{4,39}$. 
It is important that dental management prioritizes the dental problems of each patient and outlines a strategy aimed at pain removal, damage reduction and prevention of new injuries. Dental remineralization strategies should be considered to prevent loss of noncarious healthy structure and to decrease dentin hypersensitivity. Prosthetic crowns, laser therapy, fluoride varnishes and, dentifrices that promote obliteration of dentinal tubules can be considered in this process ${ }^{4}$.

\section{CONCLUSIONS}

Tricho-dento-osseous syndrome has oral manifestations relevant to dentistry. Dental enamel defects and severe taurodontism present in patients diagnosed with TDOS deserve attention for diagnostic and therapeutic purposes by the dental surgeon, although there is no clinical protocol or specific recommendations for the dental management of these patients.

\section{CONFLICT OF INTERESTS}

None of the authors of this article claim to have conflicts of interest of any kind.

\section{FINANCIAL SUPORT}

None of the authors of this article declare that they have received financial assistance to support this scientific production.

\section{REFERENCES}

1. Jain P, Kaul R, Saha S, Sarkar S. Tricho-dento-osseous syndrome and precocious eruption. J Clin Exp Dent. 2017;9(3):494-7.

2. Whitehouse LLE, Smith CEL, Poulter JA, Brown C], Patel A, Lamb T, et al. Novel DLX3 variants in amelogenesis imperfecta with attenuated tricho-dento-osseous syndrome. Oral Dis. 2019;25(1):182-91.

3. Zhao N, Han D, Liu H, Li Y, Wong SW, Cao Z, et al.. Senescence: novel insight into DLX3 mutations leading to enhanced bone formation in Tricho-Dento-Osseous syndrome. Sci Rep. 2016;6:38680.

4. Al-Batayneh OB. Tricho-dento-osseous syndrome: diagnosis and dental management. Int] Dent. 2012;2012:514692.

5. Price JA, Wright JT, Walker S], Crawford PJM, Aldred M], Hart TC. Tricho-dento-osseous syndrome and amelogenesis imperfecta with taurodontism are genetically distinct conditions. Clin Genet. 1999;56(1):35-40.

6. Robinson GC, Miller]R, Worth HM. Hereditary enamel hypoplasia: its association with characteristic hair structure. Pediatrics. 1966;37:498-502.

7. Lichtenstein JR, Warson R. Syndrome of dental anomalies, curly hair, and sclerotic bone. Birth Defects Orig Artic Ser. 1971;7:308-11.

8. Lichtenstein JR, Warson R, Jorgenson R, Dorst JP, McKusick VA. The tricho-dento-osseous (TDO) syndrome. Am J Hum Genet. 1972;24:569-82.

9. Quattromani F, Shapiro SD, Young RS, Jorgenson R], ParkerJW, Blumhardt R. Clinical heterogeneity in the trichodento-osseous syndrome. Hum Genet. 1983;64:116-21.

10. Shapiro SD, Quattromani FL, Jorgenson R], Young RS. Tricho-dento-osseous syndrome: heterogeneity or clinical variability. Am ] Med Genet. 1983;16:225-36.

11. SeowWK. Trichodentoosseous (TDO) syndrome: case report and literature review. Pediatr Dent. 1993;15:355-61.

12. Seow WK. Taurodontism of the mandibular first permanent molar distinguishes between the tricho-dento-osseous (TDO) syndrome and amelogenesis imperfecta. Clin Genet. 1993;43(5):240-6. 
13. Hart TC, Bowden DW, Bolyard ], Kula K, Hall K, Wright]T. Genetic linkage of the tricho-dento-osseous syndrome to chromosome 17q21. Hum Mol Genet. 1997;6(13):2279-84.

14. Price JA, Bowden DW, Wright JT, Pettenati M], Hart TC. Identification of a mutation in DLX3 associated with tricho-dento-osseous (TDO) syndrome. Hum Mol Genet. 1998;7(3):563-9.

15. Price JA, Wright JT, Kula K, Bowden DW, Hart TC. A common DLX3 gene mutation is responsible for tricho-dento-osseous syndrome in Virginia and North Carolina families. ] Med Genet. 1998;35:825-28.

16. Wright JT, Kula K, Hall K, Simmons JH, Hart TC. Analysis of the tricho-dento-osseous syndrome genotype and phenotype. Am ] Med Cenet. 1997;72(2):197-204.

17. Dong ], Amor D, Aldred M], Gu T, Escamilla M, MacDougall M. DLX3 mutation associated with autosomal dominant amelogenesis imperfecta with taurodontism. Am ] Med Genet A. 2005;133A(2):138-41.

18. Wright JT, Hong SP, Simmons D, Daly B, Uebelhart D, Luder HU. DLX3 C.561_562delCT mutation causes attenuated phenotype of tricho-dento-osseous syndrome. Am ] Med Genet A. 2008;146A(3):343-9.

19. Duverger O, Lee D, Hassan MQ, Chen SX, Jaisser F, Lian JB, et al. Molecular consequences of a frameshifted DLX3 mutant leading to Tricho-Dento-Osseous syndrome. J Biol Chem. 2008;283(29):20198-208.

20. Choul-Mazgar S, Hotton D, Lézot F, Blin-Wakkach C, Asselin A, Sautier]M, et al. Expression pattern of Dlx3 during cell differentiation in mineralized tissues. Bone. 2005;37(6):799-809.

21. Zhang Z, Tian H, Lv P, Wang W, Jia Z, Wang S, et al. Transcriptional factor DLX3 promotes the gene expression of enamel matrix proteins during amelogenesis. PLoS One. 2015;10(3):e0121288.

22. Zeng L, Zhao N, Han D, Liu H, Liu Y, Wang Y, et al. DLX3 mutation negatively regulates odontogenic differentiation of human dental pulp cells. Arch Oral Biol. 2017;77:12-7.

23. Zeng L, Zhao N, Li F, Han D, Liu Y, Liu H, et al. miR-675 promotes odontogenic differentiation of human dental pulp cells by epigenetic regulation of DLX3. Exp Cell Res. 2018;367(1):104-11.

24. Nguyen T, Phillips C, Frazier-Bower S, Wright T. Craniofacial variations in the tricho-dento-osseous syndrome. Clin Genet. 2013;83(4):375-9.

25. Hegde V, Srikanth K. Interradicular dentin dysplasia associated with amelogenesis imperfecta with taurodontism or trichodentoosseous syndrome: a diagnostic dilemma. Indian ] Dent Res. 2014;25(2):269-71.

26. Crawford PJM, Aldred M]. Amelogenesis Imperfecta with taurodontism and the trichodentoosseous syndrome separate conditions or a spectrum of disease. Clin Genet. 1990;38:44-50.

27. Pavlic A, Lukinmaa PL, Nieminen P, Kiukkonen A, Alaluusua S. Severely hypoplastic amelogenesis imperfecta with taurodontism. Int ] Paediatr Dent. 2007:17(4):259-66.

28. Li Y, Han D, Zhang H, Liu H, Wong S, Zhao N, et al. Morphological analyses and a novel de novo DLX3 mutation associated with tricho-dento-osseous syndrome in a Chinese family. Eur ] Oral Sci. 2015;123(4):228-34.

29. Spangler CS, Hall KI, Kula K, Hart TC, Wright]T. Enamel structure and composition in the tricho-dento-osseous syndrome. Connect Tissue Res. 1998;39(1-3):165-75.

30. Seow WK, Lai PY. Association of taurodontism with hypodontia: a controlled study. Pediatr Dent. 1989;11(3):214-9.

31. Kula K, Hall K, Hart T, Wright JT. Craniofacial morphology of the tricho-dento-osseous syndrome. Clin Genet. 1996;50(6):446-54.

32. Islam M, Lurie AG, Reichenberger E. Clinical features of tricho-dento-osseous syndrome and presentation of three new cases: an addition to clinical heterogeneity. Oral Surg Oral Med Oral Pathol Oral Radiol Endod. 2005;100(6):736-42.

33. Mayer DE, Baal C, Litschauer-Poursadrollah M, Hemmer W, Jarisch R. Uncombable hair and atopic dermatitis in a case of trichodento-osseous syndrome. J Dtsch Dermatol Ges. 2010;8(2):102-4

34. Al Kaissi A, Skoumal M, Roetzer K, Grill F, Klaushofer K. A patient with melorheostosis manifesting with features similar to tricho-dento-osseous syndrome: a case report. ] Med Case Rep. 2008;19;2:51.

35. Harbuz R, Bilan F, Couet D, Charraud V, Kitzis A, Gilbert-Dussardier B. Osteogenesis imperfecta, tricho-dento-osseous syndrome and intellectual disability: a familial case with 17q21.33-q22 (COL1A1 and DLX3) deletion and 7932.3-q33 duplication resulting from a reciprocal interchromosomal insertion. Am ] Med Cenet A. 2013;161A(10):2504-11.

36. Yokoi T, Saito T, Nagai ]l, Kurosawa K. 17q21.32-q22 Deletion in a girl with osteogenesis imperfecta, tricho-dento-osseous syndrome, and intellectual disability. Congenit Anom (Kyoto). 2019;59(2):51-2.

37. Seow WK. Developmental defects of enamel and dentine: challenges for basic science research and clinical management. Aust Dent ]. 2014;59 Suppl 1:143-54.

38. Ceyhan D, Kirzioglu Z, Emek T. A long-term clinical study on individuals with amelogenesis imperfecta. Niger J Clin Pract. 2019;22(8):1157-62.

39. Sabandal MM, Schäfer E. Amelogenesis imperfecta: review of diagnostic findings and treatment concepts. Odontology. 2016;104(3):245-56. 